\title{
Generating Employment For Turkey: Policy Alternatives In Comparison With Selected Countries
}

\author{
Mehmet Huseyin Bilgin, (E-mail: mhbilgin@khas.edu.tr), Kadir Has University, Istanbul, Turkey \\ M. Cem Toker, (E-mail: mcemtoker@ csgb.gov.tr), The Turkish Ministry of Labor and Social Security, Ankara, Turkey \\ Ender Demir, (E-mail: edemir@khas.edu.tr), Kadir Has University, Istanbul, Turkey
}

\begin{abstract}
The main purpose of this paper is to provide some lessons for Turkey from the experiences of some selected countries that gained success in their fight against unemployment. In this respect, the experiences of selected countries; Ireland, Netherlands, United Kingdom and South Korea will be analyzed and the policy options for Turkey will be formed up. It is expected that the detailed analysis and comparison of the reforms in labor markets of these countries will put forward essential and applicable results. It is also supposed that our results will greatly contribute to the decrease in the unemployment level in Turkey, when applied. By doing so, this paper endeavors to get some meaningful policy findings for Turkey. In addition, it is believed that the comparison of the labor markets of these countries, the economic structures and labor markets of which are fairly different from each other will result in interesting findings.
\end{abstract}

\section{INTRODUCTION}

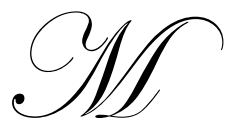

any countries experienced high unemployment rates in the 1990s. In many countries, the unemployment rates have increased dramatically and the unemployment problem is rapidly assuming dangerous proportions in last decades. It is obvious that, there were many reasons for the increase in unemployment. It can be said that the structure of labor markets and weak economic performance were the most important reasons of the high unemployment rates. In other words, there were macroeconomic and structural dimensions of the problem. Therefore, in this period, many economies were unable to create enough jobs.

Unemployment has remained a worrisome problem at the global level. In fact, despite strong global economic growth in 2006, the global unemployment rate remained unchanged from the previous year at 6.3 percent. According to the International Labour Organization (ILO, 2007), in 2006, there were more people in work than the year before, but at the same time there were also more unemployed people than in 2005. In addition, recent trends in the labor market are worrisome. Berger and Harasty (2002) claim that if current trends are maintained, the employment prospect for the future does not look bright.

Since then, job creation became most important issue in many economies. In 1990s, government has for dealing with job creation and reduction of the high unemployment in many countries. In order to decrease unemployment, various measures have been taken and some programs implemented by governments. In this period, some countries gained success in their fight against unemployment. Ireland, Netherlands, United Kingdom and South Korea are some of the countries.

The plan of the paper is as follows. First, the experiences of some countries that gained success in their fight against unemployment will be analyzed. Then, the dynamics of unemployment and Turkish labor market will be examined. In the last section, policy reform options for Turkey will be discussed. 


\section{THE EXPERIENCES OF SELECTED COUNTRIES}

\section{Ireland}

Ireland is one of the countries that gained success in their fight against unemployment in last decades. Until the mid 1990s, unemployment rate in Ireland has been one of the highest in European Union and among OECD countries. Given that, in the period of 1973-93, there has been an underlying increase in unemployment rate. It increased from under 7 percent in 1973 to 15.6 percent in 1993 (Ronayne, 1994). The unemployment rate in 1993 was two times higher than the average of OECD countries. After mid-1990s, the unemployment rates in Ireland have decreased dramatically. As it is seen, ${ }^{1}$ Ireland outperformed other countries by a reduction in unemployment rate from 15.6 percent in 1993 to 4 percent in 2001.

Within this context, it can be said that the social partnership system has played an important role in this success story. In fact, in 1987, social partnership system was implemented with the participation of government, trade unions and the employers. As Özenen (2006) mentions, this agreement promoted wage moderation in return for the future reductions in tax burdens. It is obvious that the constraints on the wages stimulated Ireland's international competitiveness. Baccaro and Simoni (2004) claim that "there are often skeptical views as to whether social partnership really played an important role in the Irish success story". By contrast, Sweeney (2004) argues that "although social partnership was not a key driver in the Irish boom and job boom, it had made a major contribution". But after the agreement, from 1987 to 1990, the unemployment rate decreased by 3.2 percent and after that three additional social partnership programmes were applied.

In addition, in the 1990s, stability-oriented macroeconomic policies focusing on price stability, were implemented in Ireland. Along with the successful macroeconomic policies, and supply of low-cost skilled and unskilled labor and implementation of social partnership programmes increased the inflows of foreign direct investment into Ireland (Legislative Council Secretariat, 2004-05). Furthermore, Garibaldi and Mauro (2002) report that "the exogenous force driving the success of Ireland was a well-thought out strategy to attract foreign direct investment: this led to an increase in the demand for Ireland's output which in turn was accommodated by increase in employment".

In Ireland, due to several exogenous factors average real GNP growth rate was 8 percent between 1993 and 2000. It is obvious that several exogenous factors contributed this boom. As Walsh (2003) states, "since there was no marked change in the rate of increase in (labor) productivity, this output boom was accompanied by a very rapid increase in the numbers at work and eventually a sharp reduction in the unemployment rate". Moreover, Ireland has been supporting active labor market programmes (ALMPs) including temporary employment schemes, job search assistance scheme, job and part-time incentive scheme, education and training programmes. In fact, in the mid1990s, expenditures on ALMPs were about 1.7 percent of GDP, whereas the average of OECD countries was just over 1 percent (Impact Evaluation of the European Employment Strategy in Ireland, 2002).

During the 1990s, have seen a dramatic reduction in unemployment and growth in employment following unprecedented economic growth. Thus, in 1990s, Ireland has been very successful in becoming a low-unemployed country. In that framework, McCarthty (2001) focuses on three main factors in this success story. These factors are the role of foreign direct investmet, the opening to Europe and the role of social pact between unions, employers and government.

\footnotetext{
${ }^{1}$ The unemployment rates are given in appendix.
} 


\section{Netherlands}

The Netherlands have been successful in decreasing unemployment in the late 1990s. Butter and Mosch (2001) emphasize that the Netherlands experienced a remarkable economic recovery between 1982 and 2000. In fact, from 1982 to 2000 , the country managed to reduce unemployment rate from 11.4 percent to 2.8 percent by performing well from many OECD countries. Thus, as Puhani (2003) states, "the country that had been associated with the term Dutch disease in the early 1980s, suddenly became a candidate for a role model".

In this success, the agreement between social partners has played an important role. As it is known, in 1982, a central agreement was reached between the labor unions and the employers' federation. Nickell and van Ours (2000) argu that "Wassenaar Agreement and other agreements were concerning wage restraint, reduction in working hours, restoration of profit levels of firms, labor market flexibility, early retirement, and the creation of jobs". Therefore, the agreements based on a supply-side scenario. As Becker (1999) reports, this scenario is aimed which will rise the investments and so employment by enhancing competitiveness and increasing profitability with low wages.

In that framework, Netherlands changed its "labor standards by relaxing employment protection regulation in all respects (open-ended contracts, fixed term contracts and temporary work agencies)" (Belot and van Ours, 2000). The authors argue that "by the Agreement of Wassenaar, Netherlands reformed their bargaining system towards increased co-ordination between unions and employer's organization". In addition, the decrease in the reluctance of unions to part-time jobs had a positive effect on employment. As Nickell and van Ours (2000) mention, part-time jobs are useful because they give flexibility to allocate more labor towards weekly peak hours in production (e.g., in retailing) and because it attracts new labor supply.

Furthermore, part-time jobs provide new employment opportunities especially for women. As a result of the increase in part-time jobs, the labor force participation rate of women "between ages 25-54 has risen from 42 percent in 1983 to 71 percent in 1998, at least 68 percent of which work part-time. The large influx of women into the labor force has added to the labor supply which has allowed many businesses to expand their production due to lowered wages" (Beck, 2000). The increase in labor force participation rate of women has also increased the overall labor force.

The decrease in unemployment in a period while the labor force was increasing can be explained by job creation. As Pot, et al. (2001) argue, this job creation is a result of labor intensive services, moderate wage increases and positive change in attitudes of employers and employees towards part-time and temporary labor. It is obvious that, the expansion of flexible jobs and part-time employment had the main effect on the decreasing unemployment. Furhermore, Eichhorst and Konle-Seidl (2005) claim that "the overall picture of labor market reforms in the Netherlands is one of a shift from passive to activating labor market policies in the nineties while leaving the benefit level virtually untouched but tightening conditions for benefit receipt". It can be said that this helped reduce the unemployment rate and long-term unemployment.

\section{United Kingdom}

In the United Kingdom, the rate of unemployment has increased in the first half of 1990s. It reached 10.2 percent in 1993, and then started to decline. It decreased to 5.3 percent in 2000, and 4.7 percent in 2004. It is obvious that, this success was a result of the labor market reforms occurred in that period. In that framework, Belot and van Ours (2000) report that the changes in between the high and low unemployment period for successful countries are mainly the institutions backed with the decrease in tax burden, union density and coverage and replacement ratio.

On the other hand, as Nickell (2002) mentions, in this period, total taxes on labor (including payroll tax rate, income tax rate and consumption tax rate) decreased from 51 percent (1980-1987) to 44 percent (1996-2000) and union density decreased from 53 percent (1980-1987) to 35 percent (1996-1998) and 26.8 percent in 2001. Although, the effect of decline in tax burden on decreasing unemployment was doubtful, it can be said that the effect 
of decrease in the power of unions was clearer. Within this context, Pissarides (2003) claims that "the decline of union power and the reforms to monetary policy that took place in 1993 and 1997 allowed unemployment to fall without causing big wage demands and inflation".

By contrast, Werner (1999) argues that the labor market policies do not play a major role in fighting with unemployment for market-economy-orientated countries such as United Kingdom. Moreover, public expenditure in active labor market programs in United Kingdom was around 0.5 percent of GDP in the early 1990s, but it decreased to 0.38 percent of GDP in 2001 (OECD). However, after the introduction of New Deal programs in the UK in 1998, the role of active labor market policies have increased. In this respect, Eichhorst and Konle-Seidl (2005) emphasize that the British welfare state is characterized by a relatively low level of employment protection and unemployment benefits.

In addition, as Card and Freeman (2002) report, the replacement ratio on unemployment benefits was decreased from 0.26 (1980-1987) to 0.17 (1999) reaching one of the lowest ratios in European Union. Saint-Paul (2006) argues that by loosening the most labor market rigidities, it is aimed to protect people by labor market rather than by labor market rigidities. In fact, activities such as decline in union density, weak employment protection and decline in the replacement ratio were implemented in order to increase the flexibility of the labor market.

Furthermore, Schmitt and Wadsworth (2002) state that "the greater labor-market flexibility should be associated with lower unemployment and higher employment of traditionally marginalized workers: the less-skilled, particularly young workers and those with lower levels of formal education". Therefore; decrease in union power, employment protection, unemployment benefits and tax wedge and the monetary policy implemented were the key aspects while decreasing the unemployment rate to 5 percent in 2001.

\section{South Korea}

Financial crisis which has occurred at the end of 1997 caused a rapid increase in the unemployment rate. In South Korea, from 1997 to 1998, unemployment rate reached to the highest level of the last two decades by jumping from 2.6 percent to 7 percent. Although 7 percent unemployment rate is moderate when compared to OECD countries, as Korea was maintaining an unemployment rate 2 percent since 1980s, such a huge jump had a devastating effect on the country. In this period, average nominal wages per employee fell by 2.5 percent which is equal to almost 10 percent in real terms in 1998 (OECD, 2000).

The financial crisis forced the Korean government to make stand-by agreement with IMF. In other words, as Song (2000) states, "in order to stabilize the falling economy, the government implemented extensive and fundamental macroeconomics policies that would reform the fragile financial and economic structure". According to program; economic, financial and structural reforms including labor market policies were required. In 1998, representatives of government, unions and employers established the "Tripartite Commission". As Kwon (2002) reports, this committee prepared "the Master Plan for Tackling Unemployment" which reduced the requirements for benefiting from the employment insurance system.

As Hur (2000) states, before the financial crisis, on July 1995, "Korea had put into place an employment insurance system including unemployment insurance, job training, and employment maintenance/promotion subsidies". Employment insurance system were strengthened and its scope was expanded after crisis by covering all firms regardless of the size and in addition public work programs and public employment services were implemented to cope with the unemployment problem. It is well known that, job-training played an important role in the labor market policy of government. As a result of this system, "in 1998, about 0.39 million unemployed participated in and benefited from various government-sponsored job training programs, approximately eight times as many as those in the preceding year" (Hur, 2001). It is obvious that the directly adding programs implemented by government, is one of the main factors in the job creation process. 
Furthermore, Jeong (2001) argues that public work programs played an important role as income support for the long-term unemployed and female workers. In that framework, Lødemel and Dahl (2000) emphasize that the Korean government spent 3.1 billion US dollars for public work programs during 1998 and 1999. Moreover, Hur (2001) claims that the public work projects were so effective that more than 50 percent of the unemployed were found to have participated in it. In addition, "in Korea, public works programs generated 440,000 jobs in 1998 and nearly 1.2 million jobs in 1999, providing work for around 70 percent of the country's unemployed in 1999" (ESCAP, 2002/03). It must be said that after success in decreasing unemployment, the government has reduced the intensity of public work programs.

On the other hand, as Dorenbos and Vossen (2002) mention, the Korean government has increased the number of government public employment services from 52 in 1997 to 134 in 1999 and also it has eased the establishment of private agencies. As Kwon (2001) reports, according to the Ministry of Labor, "in 1998 and 1999 about 3.5 million people visited the public employment services in order to search for jobs or to register and the jobfinding rate was 7.4 (1998) and 18.7 percent (1999)". As a result of successfully implemented macroeconomic and labor market policies, in 2000, the Korean economy showed the signs of recovery and unemployment rate decreased to 4 percent. In addition, the incentives for employers such as subsidized credit, improved liquidity, avoidance of bankruptcy, and wage subsidies have been played an important role in this success (ESCAP, 2002/03).

\section{UNEMPLOYMENT IN TURKEY ${ }^{2}$}

Like many other developing countries, "Turkey's labor market outcomes reflect the interaction of demographic and economic factors... A rapid demographic transition has temporarily raised population growth" (World Bank, 2006). This demographic transition has changed the age structure and composition of the working-age population enormously, increasing the proportion of young people in the labor force. As a result, as Taymaz and Ozler (2004) argue, one of the most important characteristics of the population in Turkey is observed in the age composition. Although the last few decades have witnessed a decline in the population growth rate, as Auer and Popova (2003) report, Turkey still has the highest population growth rate among OECD countries.

With the rapid expansion of the working-age population and the increase in the proportion of young people, unemployment has become one of the most pressing problems in the Turkish economy. Today, it is widely accepted that the most important economic and social problem of Turkey is the high rate of unemployment. As Auer and Popova (2003) state, not only demographic, but also economic factors are among the main reasons for unemployment. Therefore, as Berument, et al. (2005) emphasize "it is believed that the unemployment rate should follow the trends in the economy". In fact, in the aftermath of the 2001 economic crisis, unemployment reached unprecedented levels.

According to the Turkish Statistical Institute (Turkstat) ${ }^{3}$, the unemployment rate increased to 8.4 percent in 2001 and to 10.3 percent in 2002, which was 6.5 percent in 2000 . The unemployment rate stayed at these high levels in 2003 and 2004, and only started to decline in 2005. Finally, it declined to 9.6 percent in November of 2006, with a 1 percentage points decrease compared to the same period of the previous year. In November of 2006, nonagricultural unemployment rate declined to 12.2 percent. In the same period, the number of unemployed persons were 2 million 415 thousand. However, given the present employment structure and underemployment, it must be said that the unemployment in Turkey goes far beyond the official estimate and evaluation. Moreover, Tansel and Tasci (2004) argue that the official unemployment rate understates the extent of the problem.

Nevertheless, according to the result of "Household Labour Force Survey For The Period of November 2006" (Turkstat, 2007), the composition of unemployment is also worrisome. It is concentrated among young people between 15 and 24 years of age, and among more educated people. The youth unemployment rate ${ }^{4}$ was 19.0 percent

\footnotetext{
${ }^{2}$ This section is based on M. H. Bilgin and I. N. Kilicarslan, "Unemployment in Turkey: An Analysis in Comparison with Some Selected Middle Eastern Countries", Sixth International Conference of the MEEA, March 14-16, 2007, Zayed University, Dubai, UAE.

${ }^{3}$ The important data about Turkish labor market is given in appendix.

${ }^{4}$ Population within 15-24 age group.
} 
in November of 2006. As Auer and Popova (2003) mention, there is "a dramatic increase in youth unemployment for both sexes". In fact, the unemployment rates for men and women are similar. But non-agricultural unemployment rate for women is higher than the rate for men. In November of 2006, it was 18.6 percent for women and 10.6 percent for men. There are also significant differences in the labor force participation rates of men and women. The labor force participation rate of men ( 71.8 percent) is nearly three times the rate of women ( 25 percent). In urban areas, it is more than three times. The low labor force participation rate of women can partly be explained by social and cultural factors. Moreover, there has been a decreasing trend in the labor force participation rate of women since the 1990s. In comparison to other OECD countries the overall labor force participation rate (48.2 percent) is also very low. In addition, in the period of November 2006, of those who were unemployed; 70.3 percent were male, 54.4 percent had education below high school, 34.3 percent were seeking job for one year or more, and 78.7 percent (1 million 901 thousand) had worked previously.

On the other hand, the Turkish labor market has some difficulties in both supply and demand. Today job creation is the most important issue in Turkish economy. In fact, "despite rapid economic growth, declining inflation and interest rates, and increased investments over the years, the job creation capacity of the economy has not improved, and high unemployment remained a worrisome problem" (ERF, 2006). The Turkish economy has grown continuously during the 2002-2006 period, which was one of the highest achieved in the world. Despite the existence of this impressive economic growth, the job creation capacity of the economy has remained quite slow in recent years.

As Taymaz and Ozler (2004); Ansal, et al. (2000); and others argue, the job creation capacity of the economy has become a very important social issue. Within this context, the rapid population growth and constantly increasing labor supply show that the job creation will continue to be a challenge of the Turkish economy in the future (ERF, 2006). Gürsel, et al. (2002) claim that in order to approximate the level of employment and supply of labor force, the Turkish economy must grow by 6 percent each year until 2010. In addition, Turkey must create between 600-650 thousand jobs each year. According to the World Bank's Report (World Bank, 2006), Turkey will have to create about 10 million jobs in six years to reach the current EU average employment rate in 2010, and will have to create about 14 million jobs to reach the Lisbon target employment rate.

\section{CONCLUSION AND SOME POLICY OPTIONS FOR TURKEY}

Today, it is widely accepted that the most important economic and social problem of Turkey is the high rate of unemployment. Within this context, the future of unemployment in Turkey has been discussed seriously for the last years. From this perspective, it can be said that today job creation is the most important issue in Turkish economy. When the level and composition of unemployment in Turkey are considered, it is easy to say that Turkey must implement policies, which will cover numerous reforms in labor market, and create jobs and decrease unemployment rate.

In this framework, in order to create jobs and decrease unemployment rate Turkey must implement the following policies:

- $\quad$ Active labor market policies,

- Human Resources Development (HRD) approach,

- $\quad$ Enhancing the coordination between labor market and vocational training,

- $\quad$ Enhancing the the proportion of vocational training (now it is about 35 percent),

- $\quad$ Enhancing the rate of women participation to labor force and employment rate,

- $\quad$ Flex-security approach,

- $\quad$ Combating against undeclared work. 


\section{REFERENCES}

1. Ansal, H. et al. (2000). Türkiye'de Emek Piyasasının Yapısı ve Işsizlik. Istanbul: Türkiye Ekonomik ve Toplumsal Tarih Vakfi Publication.

2. Auer, P. \& Popova, N. (2003). Labour market policy for restructuring in Turkey: The need for more active policies. International Labour Office. Employment Paper, 2003/51, www.ilo.org

3. Baccaro, L. \& Simoni, M. (2004). The Irish social partnership and the celtic tiger phenomenon. International Institute for Labour Studies. Disccussion Paper, DP/154/2004, www.ilo.org

4. Beck, N. (2000). The Netherlands: A Model for Macro-Economic Development. Social Science, 410, November 2000, www.andover.edu/aep/papers/410/nbeck00.pdf

5. Becker, U. (1999). The Dutch Miracle Employment Growth in a Retrenched But Still Generous Welfare System. Social Policy Research Centre. Discussion Paper, No.99, May 1999.

6. Belot, M. \& van Ours, J. C. (2000). Does the Recent Success of Some OECD Countries in Lowering their Unemployment Rates Lie in the Clever Design of their Labor Market Reforms?. IZA Discussion Paper, No.147, April 2000.

7. Berger, S. \& Harasty, C. (2002). World and Regional Employment Prospects: Halving the World's Working Poor by 2010. International Labour Organization. Employment Paper, 38, www.ilo.org

8. Berument, H. et al. (2005). Economic Performance and Unemployment: Evidence From An Emerging Economy-Turkey. IZA Discussion Paper, 1614, May 2005.

9. Bilgin, M. H. \& Kilicarslan, I. N. (2007). Unemployment in Turkey: An Analysis in Comparison with Some Selected Middle Eastern Countries. Sixth International Conference of the MEEA, March 14-16, 2007, Zayed University, Dubai, UAE.

10. Butter, F. A. G. den \& Mosch, R. H. J. (2001). The Dutch Miracle: Institutions, Networks and Trust. Serie Research Memoranda, 200 1-18, Free University, Amsterdam, Faculty of Economics, Business Administration and Econometrics.

11. Card, D. \& Freeman, R. B. (2002). What Have Two Decades of British Economic Reform Delivered?. NBER Working Paper Series, 8801, February 2002.

12. Dorenbos, R. \& Vossen, I. (2002). Public employment services: Can East Asia learn from the experience in Europe? Final Version, NEI Labour and Education, Rotterdam, February 2002.

13. Eichhorst, W. \& Konle-Seidl, R. (2005). The Interaction of Labor Market Regulation and Labor Market Policies in Welfare State Reform. IZA Discussion Paper, 1718, August 2005.

14. ERF. (2006). Turkey Country Profile: The Way Ahead for Turkey. Economic Research Forum. www.erf.org.eg

15. ESCAP. (2002/03). A Note on Unemployment in the Wake of the Asian Economic Crisis and Some Responses. Development Research and Policy Analysis Division, Bulletin on Asia-Pacific Perspectives, 2002/03.

16. Garibaldi, P. \& Mauro, P. (2002). Anatomy of Employment Growth. Economic Policy. Volume 17, Number 34, April 2002, pp.67-113.

17. Gürsel, S. et al. (2002). Türkiye'de İşgücü Piyasası ve İssizlik. Istanbul: TÜSİAD-T/2002/12-354.

18. Hur, J. J. (2001). Economic Crisis, Income Suport, and Employment Generating Programs: The Korea's Experience. Paper prepared for the UN ESCAP regional seminar on Evaluation of Income/Employment Generating Programs to Alleviate Socio-Economic Impacts of the Economic Crisis, Bangkok, May 23-25, 2001.

19. Hur, J. J. (2000). Expanding the Coverage of Korea's Unemployment Insurance System. Paper prepared for the World Bank/KLI conference on Reforming Social Protection for Workers in Korea, Seoul, May 18-20, 2000 .

20. ILO. (2007). Global Employment Trends, Brief. International Labour Office. 25 January 2007. www.ilo.org

21. Impact Evaluation of the European Employment Strategy in Ireland, http://www.entemp.ie/publications/labour/2002/eesimpactevaluation.pdf

22. Jeong, I. (2001). Unemployment Schemes since the Financial Crisis in Korea: Achievements and Evaluations. Korea Labor Institute. Issue Paper, No.2, December 2001. 
23. Kwon, H. J. (2002). Unemployment and Public Work Projects in Korea, 1998-2000. Reference Materials for the ADBI Seminar on Social Protection for the Poor in Asia and Latin America. Manila, 21-25 October, 2002.

24. Kwon, H. J. (2001). Globalization, Unemployment and Policy Responses in Korea: Repositioning the State?. Global Social Policy, Vol. 1, No. 2, pp.213-234.

25. Legislative Council Secretariat. (2004-05). Unemployment in Ireland. Research and Library Services Division. FS12/04-05.

26. Lødemel, I. \& Dahl, E. (2000). Public Works Programmes in Korea A comparison to Active Labour Market Policies and Workfare in Europe and the US. Preliminary Report prepared for the World Bank. 5.5.2000.

27. McCharty, F. D. (2001). Social Policy and Macroeconomics: The Irish Experience. Policy Research Working Paper, Number 2736, The World Bank.

28. Nickell, S. (2002). A Picture of European Unemployment: Success and Failure. Paper has been prepared for the Conference Unemployment in Europe: Reasons and Remedies, organised by the Yrjö Jahnsson Foundation and CESifo. November 2002.

29. Nickell, S. \& van Ours, J. (2000). Why Has Unemployment in the Netherlands and the United Kingdom Fallen so Much?. Canadian Public Policy, Volume 26, Issue 1 (July), pp.201-220.

30. OECD. (2000). Labour market reform and social safety net policies in Korea. Policy Brief, October 2000, WWW.oecd.org.

31. OECD. Employment Outlook 1996 and 2003.

32. Özenen, C. G. (2006). The Effects of Structural Funds on Ireland's Development and Lessons for Turkey. State Planning Organization. General Directorate of Economic Sectors and Coordintion Department of Infrastructure and Services. May 2006.

33. Pissarides, C. A. (2003). Unemployment in Britain: A European Success Story. Cesifo Working Paper, No.9821, July 2003.

34. Pot, F. et al. (2001). Contingent Employment in the Netherlands. ERIM Report Series Research in Management, ERS-2001-04-ORG, January 2001.

35. Puhani, P. A. (2003). What Happened to Wage and Non-Employment Structures During the Dutch Employment Miracle?. Discussion Paper, 2004-04. University of St. Gallen, Department of Economics, November 2003.

36. Ronayne, T. (1994). Regions Without Work Unemployment and Labour Market Policy in Ireland. Paper prepared for OSB Consultants (International Division). Neubaugasse 31/1/10, A-1070 Vienna, January 1994.

37. Saint-Paul, G. (2006). Alternative strategies for fighting unemployment: lessons from the European Experience. Paper was prepared for the conference at Centro de Estudios Publicos, Santiago de Chile, December 12, 2006.

38. Schmitt, J. \& Wadsworth, J. (2002). Is the OECD Jobs Strategy Behind US and British Employment and Unemployment Success in the 1990s?. CEPA Working Paper, 2002-06, June 2002.

39. Song, M. S. (2000). Korea's Fast Recovery: The Role of Macroeconomic Policies and Reform Programs. Social Science, 410, November 2000.

40. Sweeney, P. (2004). The Irish Experience of Economic Lift Off (With a focus on the Contribution of Social Partnership and the Potential Contribution of Life-Long Learning). A Colloquium Celebrating Ireland's Presidency of the European Union. Montreal, May 2004.

41. Tansel, A. \& Tasci, H. M. (2004). Determinants of Unemployment Duration For Men and Women in Turkey. Turkish Economic Association. Discussion Paper, 2004/6, March 2004. www.tek.org.tr

42. Taymaz, E. \& Ozler, S. (2004). Labor Market Policies and EU Accession: Problems and Prospects for Turkey. Economic Research Center, Middle East Technical University. ERC Working Paper in Economic, 04/05, March 2004.

43. TURKSTAT. (2007). Household Labour Force Survey For The Period of November 2006 (October, November, December 2006). Turkish Statistical Institute. Press Release, 22, February 15, 2007. www.tuik.gov.tr

44. Walsh, B. (2003). When Unemployment Disappears: Ireland in the 1990s. Cesifo Working Paper, No.856, Ferbruary 2003. 
45. Werner, H. (1999). Countries With Successful Employment Policy-What Is Behind Their Success? IAB Labour Market Research Topics 33.

46. World Bank. (2006). Turkey: Labor Market Study. Report No. 33254-TR. World Bank. April 14, 2006. www.worldbank.org

\section{Appendix}

Table 1: Unemployment Rates of Selected Countries, and EU-15 and OECD

\begin{tabular}{ccccccc}
\hline Years & Ireland & Netherlands & $\begin{array}{c}\text { United } \\
\text { Kingdom }\end{array}$ & South Korea & EU-15 & OECD-Total \\
$\mathbf{1 9 8 9}$ & 14,7 & 6,6 & 7,1 & 2,6 & 8,7 & 6,2 \\
$\mathbf{1 9 9 0}$ & 13,4 & 5,9 & 6,9 & 2,4 & 8,1 & 6,1 \\
$\mathbf{1 9 9 1}$ & 14,7 & 5,5 & 8,6 & 2,4 & 8,4 & 6,8 \\
$\mathbf{1 9 9 2}$ & 15,4 & 5,3 & 9,8 & 2,5 & 9,1 & 7,4 \\
$\mathbf{1 9 9 3}$ & 15,6 & 6,2 & 10,2 & 2,9 & 10,0 & 7,8 \\
$\mathbf{1 9 9 4}$ & 14,3 & 6,8 & 9,3 & 2,5 & 10,4 & 7,6 \\
$\mathbf{1 9 9 5}$ & 12,3 & 6,6 & 8,5 & 2,1 & 10,0 & 7,2 \\
$\mathbf{1 9 9 6}$ & 11,7 & 6,0 & 7,9 & 2,0 & 9,8 & 7,2 \\
$\mathbf{1 9 9 7}$ & 9,9 & 4,9 & 6,8 & 2,6 & 9,2 & 6,9 \\
$\mathbf{1 9 9 8}$ & 7,5 & 3,8 & 6,1 & 7,0 & 8,5 & 6,8 \\
$\mathbf{1 9 9 9}$ & 5,7 & 3,2 & 5,9 & 6,6 & 7,6 & 6,6 \\
$\mathbf{2 0 0 0}$ & 4,3 & 2,8 & 5,3 & 4,4 & 7,2 & 6,2 \\
$\mathbf{2 0 0 1}$ & 4,0 & 2,2 & 5,0 & 4,0 & 7,6 & 6,4 \\
$\mathbf{2 0 0 2}$ & 4,5 & 2,8 & 5,1 & 3,3 & 7,9 & 6,9 \\
$\mathbf{2 0 0 3}$ & 4,7 & 3,7 & 4,9 & 3,6 & 8,0 & 7,1 \\
$\mathbf{2 0 0 4}$ & 4,5 & 4,6 & 4,7 & 3,7 & 3,9 & 6,9 \\
$\mathbf{2 0 0 5}$ & 4,3 & 4,7 & 4,8 & 3,7 & 7,4 & 6,0 \\
$\mathbf{2 0 0 6}$ & 4,4 & 3,9 & 5,3 & 3,5 & & 6,6 \\
\hline
\end{tabular}

Source: OECD Statistics, http://stats.oecd.org/wbos/Default.aspx

Table 2: Labour Force Status in Turkey

\begin{tabular}{|c|c|c|c|c|c|c|c|}
\hline & 2000 & 2001 & 2002 & 2003 & 2004 & 2005 & $2006^{1}$ \\
\hline Non-institutional civilian population (000) & 66187 & 67296 & 68393 & 69479 & 70556 & 72006 & 72957 \\
\hline Population 15 years old and over $(000)$ & 46211 & 47158 & 48041 & 48912 & 49906 & 51146 & 52000 \\
\hline Labour force $(000)$ & 23078 & 23491 & 23818 & 23640 & 24289 & 24539 & 25056 \\
\hline Employed (000) & 21581 & 21524 & 21354 & 21147 & 21791 & 21928 & 22641 \\
\hline Unemployed $(000)$ & 1497 & 1967 & 2464 & 2493 & 2498 & 2611 & 2415 \\
\hline Labour force participation rate (\%) & 49,9 & 49,8 & 49,6 & 48,3 & 48,7 & 48,0 & 48,2 \\
\hline Employment rate (\%) & 46,7 & 45,6 & 44,4 & 43,2 & 43,7 & 42,9 & 43,5 \\
\hline Unemployment rate $(\%)$ & 6,5 & 8,4 & 10,3 & 10,5 & 10,3 & 10,6 & 9,6 \\
\hline Non-agricultural unemployment rate (\%) & 9,3 & 12,4 & 14,5 & 13,8 & 14,3 & 13,7 & 12,2 \\
\hline Youth unemployment rate ${ }^{(2)}(\%)$ & - & - & - & 20,5 & 19,7 & 19,6 & 19,0 \\
\hline Underemployment rate $(\%)$ & 6,9 & 6,0 & 5,4 & 4,8 & 4,1 & 3,3 & 3,0 \\
\hline Underemployment rate of youth ${ }^{(2)}(\%)$ & - & - & - & 6,5 & 5,1 & 3,9 & 3,4 \\
\hline $\begin{array}{l}\text { Not in the labour force }(\mathbf{0 0 0}) \\
\text { (1) November } \\
\text { (2) Population within 15-24 age group }\end{array}$ & 23133 & 23667 & 24223 & 25272 & 25616 & 26607 & 26944 \\
\hline
\end{tabular}

Source: Turkish Statistical Institute, Household Labour Force Survey, www.tuik.gov.tr 
NOTES 